Review Article

\title{
The pathophysiological role of serotonin receptor systems in opioid analgesia and tolerance
}

\author{
Ercan Ozdemir*
}

Departments of Physiology, Cumhuriyet University School of Medicine, 58140 Sivas, Turkey

Received: 14 December 2016 Accepted: 04 January 2017

\section{*Correspondence to:}

Dr. Ercan Ozdemir,

Email:

ercan_ozdemir@hotmail.com

Copyright: (๑) the author(s), publisher and licensee Medip Academy. This is an openaccess article distributed under the terms of the Creative Commons Attribution NonCommercial License, which permits unrestricted noncommercial use, distribution, and reproduction in any medium, provided the original work is properly cited.

\begin{abstract}
Continuous treatment with opioid analgesics, such as morphine, leads to the development of ant nociceptive tolerance in patients. Although a lot of information about antinociceptive, the pathophysiological mechanisms of tolerance to opioid analgesia are not yet completely understood. Proposed mechanisms for opioid analgesic tolerance comprise down-regulation of opioid receptors, reduction of sensitivity G-proteins, altered intracellular signalling pathway including nitric oxide, adenyl cyclase, and protein kinase C. Numerous physiological and behavioural studies have shown an interaction of the serotonergic system and opioid antinociception. The serotonin (5-HT) receptor system is a necessary component of the spinal and midbrain pain modulation circuit mediating opioid analgesia. Various types of serotonin receptors demonstrate different effects on morphine analgesia. Systemic administration of opioids rise 5-HT levels in the spinal cord dorsal horn and contribute to opioid analgesia in the normal state but reduce that in neuropathic pain via spinal 5HT3 receptors. Spinal and supraspinal serotonergic neurons may also play a pathophysiological role in the development of morphine analgesic tolerance. Serotonin receptor subtypes show different effects on opioid tolerance. This review paper focus on the current understanding of the role of serotonin receptor systems in opioid analgesia and tolerance.
\end{abstract}

Keywords: Opioid receptors, Opioid tolerance, Serotonin receptors, Serotonin analgesia, Tolerance mechanism

\section{INTRODUCTION}

Though opioid analgesic drugs are still the principal treatment for severe chronic pain, continuous use of opioids is known to result in a decreased antinociceptive effect, also known as antinociceptive tolerance. ${ }^{1,2}$ Antinociceptive tolerance is described as the reduction in analgesic efficacy of a drug after a previous exposure to the same drug dose. Thus, higher doses of the drug are necessary to show the same amount of analgesic effect. High doses of opioid drugs result in important unwanted effects such as nausea, constipation, vomiting, somnolence, dizziness, and deterioration of mental

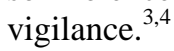

The pathophysiological mechanism underlying the development of opioid analgesic tolerance maintains obscure. It has been suggested that opioid analgesic tolerance is a result of 1) down-regulation of opioid receptors $(\mu, \delta$, and $\kappa), 2)$ decreased sensitivity of heterotrimeric G-proteins, 3) changed cellular signaling pathway including nitric oxide, adenyl cyclase or protein kinase $C$ and 4) participation of postreceptor cellular occurrences, especially the $\gamma$-aminobutyric acid (GABA), glutamate, and monoamine neurotransmitters such as noradrenaline and serotonin (5-hydroxytryptamine, 5HT).$^{5}$

The rostral ventromedial medulla (RVM) forms part of a descending pathway that regulates pain transmission at the level of the spinal cord dorsal horn. In addition, RVM is a critical site for the supraspinal antinociceptive actions and analgesic tolerance to opioids. Animals with lesion of the dorsolateral funiculus (DLF) did not demonstrate enhanced neuropeptide release and antinociceptive tolerance upon sustained exposure to opioid drugs. 
Injection of lidocaine into the RVM inhibited both thermal hyperalgesia and analgesic tolerance to morphine in rats. ${ }^{6,7}$

Many pharmacological agents have been shown to inhibit antinociceptive tolerance. These agents include: nitric oxide (NO) synthase inhibitors, calcium channel blockers, substance $\mathrm{P}$ receptor (NK-1) antagonists, calcitonin gene-related peptide (CGRP) receptor antagonists, cyclooxygenase (COX) inhibitors, antagonists of the NMDA (N-methyl-D-aspartate) receptor, cholecystokinin (CCK) receptor antagonists, and 5-HT receptor agonists. ${ }^{8-17}$

Serotonergic neurons are involved in the formation of spinal cord pain. ${ }^{18}$ Stimulation of serotonergic neurons decreases the pain responses through a descending inhibitory pathway in the spinal cord dorsal horn. ${ }^{19}$ The antinociceptive effect of morphine was blocked by the 5HT receptor antagonist methysergide when injected into the periaqueductal gray (PAG) in midbrain. ${ }^{20}$ Additionally, opioid induces the release of 5-HT in different serotonergic neuron areas, originated primary from the dorsal raphe nucleus (DRN). ${ }^{21}$ Morphine seems to act in the area of the DRN to produce rised extracellular 5-HT levels in several midbrain sites. ${ }^{22}$ It has been suggested that sustained administration of morphine leads to an increase in GABA levels and later to a reduce in serotonergic activity in the DRN neurons. Thus, it may be supposed that the dorsal and median raphe serotonergic neuron systems have significant roles in the appearance of opioid tolerance. There is argument showing a correlation between the synthesis rate of 5-HT in the midbrain and the development of tolerance, supporting a pathophysiological role of 5-HT in opioid analgesic tolerance. ${ }^{23,24}$ In addition, it has been shown that $8-\mathrm{OH}-\mathrm{DPAT}$, a specific $5-\mathrm{HT}_{1 \mathrm{~A}}$ receptor agonist, inhibits morphine analgesic tolerance. ${ }^{25}$

This review focus on the mechanisms of mophine antinociceptive tolerance and pathophysiological role of serotonin receptor systems in opioid analgesia and tolerance.

\section{OPIOID RECEPTOR PHYSIOLOGY}

Opioid receptors have belonged to the major family of seven transmembrane $G$ protein-coupled receptors (GPCR) with opioids as ligands. ${ }^{26}$ The endogenous opioids are dynorphins, enkephalins, endorphins and nociceptin. Three large opioid receptor families, the $\mu_{-}^{-}, \kappa$, and $\delta$ - receptor subtypes, were cloned in 1990 and the nociceptin or orphanin FQ receptor (NOR), a fourth member of the opioid receptor subtype, was attached to the list in 1994 (Table 1). ${ }^{27-29}$ Opioid receptors are distributed widely in the brain, and are found in the spinal cord, heart, liver, lungs and digestive tract. ${ }^{30}$

Numerous studies indicate that the pharmacological interactions between opioid receptors play a crucial role in defining their resultant physiologically behaviors. ${ }^{31}$ For instance, $\delta$-agonist drugs were displayed to increase the antinociceptive potency of $\mu$-agonists, and $\delta$-antagonists attenuated the development of tolerance to opioid analgesia by $\mu$-agonists. ${ }^{32}$

Table 1: Opioid receptors subtypes, locations and functions.

\begin{tabular}{|c|c|c|c|}
\hline Receptor & Subtypes & Location & Function \\
\hline $\begin{array}{l}\operatorname{mu}(\mu) \\
\operatorname{MOR}\end{array}$ & $\mu_{1}, \mu_{2}, \mu_{3}$ & $\begin{array}{ll}\text { - } & \text { cortex } \\
\text { - } & \text { thalamus } \\
\text { - } & \text { PAG } \\
\text { - } & \text { spinal cord } \\
\text { - } & \text { peripheral sensory neurons } \\
\text { - } & \text { intestinal tract }\end{array}$ & $\begin{array}{ll}\text { - } & \text { analgesia }\left(\mu_{1}\right) \\
\text { - } & \text { intestinal motility }\left(\mu_{2}\right) \\
\text { - } & \text { respiratory depression }\left(\mu_{2}\right) \\
\text { - } & \text { physical dependence }\left(\mu_{1}\right) \\
\text { - } & \text { euphoria }\left(\mu_{2}\right) \\
\text { - } & \text { miosis }\left(\mu_{2}\right) \\
- & \text { vasodilation }\left(\mu_{3}\right)\end{array}$ \\
\hline $\begin{array}{l}\text { delta }(\delta), \\
\text { DOR }\end{array}$ & $\delta_{1}, \delta_{2}$ & $\begin{array}{ll}\text { - } & \text { pontine nuclei } \\
\text { - } & \text { amygdala } \\
\text { - } & \text { olfactory bulbs } \\
\text { - } & \text { peripheral sensory neurons }\end{array}$ & $\begin{array}{ll}\text { - } & \text { analgesia } \\
\text { - } & \text { convulsant effects } \\
\text { - } & \text { antidepressant effects } \\
\text { - } & \text { physical dependence }\end{array}$ \\
\hline $\begin{array}{l}\text { Kappa }(\mathrm{K}) \text {, } \\
\text { KOR }\end{array}$ & $\kappa_{1}, \kappa_{2}, \kappa_{3}$ & $\begin{array}{ll}\text { - } & \text { brain } \\
\text { - } & \text { hypothalamus } \\
\text { - } & \text { PAG } \\
\text { - } & \text { spinal cord } \\
\text { - } & \text { peripheral sensory neurons }\end{array}$ & $\begin{array}{ll}\text { - } & \text { analgesia } \\
\text { - } & \text { depression } \\
\text { - } & \text { dysphoria } \\
\text { - } & \text { miosis } \\
\text { - } & \text { neuroprotection } \\
\text { - } & \text { sedation } \\
\text { - } & \text { stress } \\
\end{array}$ \\
\hline $\begin{array}{l}\text { Nociceptin } \\
\text { Receptor, NOR }\end{array}$ & $\mathrm{ORL}_{1}$ & $\begin{array}{ll}\text { - } & \text { cortex } \\
\text { - } & \text { hippocampus } \\
\text { - } & \text { amygdala } \\
\text { - } & \text { hypothalamus } \\
\text { - } & \text { spinal cord }\end{array}$ & $\begin{array}{ll}- & \text { appetite } \\
\text { - } & \text { anxiety } \\
\text { - } & \text { depression }\end{array}$ \\
\hline
\end{tabular}


LY255582, an opioid antagonist, which formed effects on feeding via a heteromeric combination of $\mu$-opioid receptor, $\delta$-opioid receptor and $\kappa$-opioid receptor. ${ }^{33}$ For this reason, new ligands with dual $\mu$-/ $\delta$-agonism or antagonism, or mixed $\mu$-agonism $/ \delta$-antagonism are arising as encouraging original attempts to the development of antinociceptive drugs. ${ }^{32}$

\section{OPIOID RECEPTOR SUBTYPES}

\section{Mu Opioid Receptor (MOR)}

The MOR was the latest of the known all opioid receptors to be cloned. MOR is found high density in the cerebral cortex, amygdala, caudate putamen and PAG. MOR is located presynaptic terminals on primary afferent neurons within the dorsal horn of the spinal cord. These receptors prevent transmission of pain stimuli from $\mathrm{A} \delta$ and $\mathrm{C}$ fibres. $^{34}$ The periaqueductal grey involves in the supraspinal control of pain signal transmission in the midbrain. The efferent PAG signals descend to the spinal cord where it acts to block pain signal in primary afferent neurons. The opioids analgesia is recommend to come about from removal of an inhibitory GABA-ergic tone in the PAG region. The fundemental inhibitory neurotransmitter GABA acts to decrease pain signal from the PAG. ${ }^{35}$

Major side-effects of MOR agonists contain respiratory depression via impaired sensitivity of chemoreceptors in lungs. MOR agonists block gastrointestinal tract peristalsis and frequently cause constipation. ${ }^{36}$ MORs also have effects on the immune function, thermoregulation, heart, vascular system and endocrine system. MOR knockout mice suggest significantly enhanced sensitivity to thermal pain sensations. ${ }^{34,37}$ None of the side-effects of opioid were shown in mice lacking the MOR. In addition, morphine did not create antinociception or respiratory depression in this mice. These findings support that both the wanted and sideeffects of opioid are attributable to action at the MOR. ${ }^{38}$

\section{Delta Opioid Receptor (DOR)}

The DOR was the first opioid receptor subtypes to be cloned and is found in the cerebral cortex, the nucleus accumbens and caudate putamen. DORs are located presynaptic terminal on primary afferent neurons and they prevent the release of transmitters. These receptors are involved in the analgesic actions of opioids via both spinal and supraspinal sites. DOR agonists have also been suggested to decrease intestinal tract peristaltic movements and cause unwanted effect on respiratory system. $^{39}$

Studies with DOR knockout mice indicated that they show hyperactive locomotor behaviour and it is presumed the receptor, under normal conditions, may depress locomotor activity. Researchers have also reported that
DOR knockout mices display depressive and anxiogenic behaviours. $^{40}$

\section{Kappa Opioid Receptor (KOR)}

The KOR was the second of the four subtypes opioid receptor to be cloned. The kappa receptor agonist is the benzomorphan ketocyclazocine, the actions of which have been shown to be distinct from those elicited by stimulation of the MOR. The activation KOR by agonists is coupled to the $\mathrm{Gi}$ protein in cell membrane, which substantially enhances phosphodiesterase enzyme activity in cell cytoplasm. Thus, intracellular phosphodiesterase enzyme breaks down cAMP, producing an inhibitory effect on pain signal transmission. ${ }^{41}$ The KOR effects include altering pain perception, consciousness, mood, and motor control. KOR agonists are potently analgesic agents and have been used clinically in the treatment of severe and chronic pain, consistent with MOR agonists. Spiradoline and enadoline, as a KOR agonists, have experienced clinical trials for their antinociceptive effects. ${ }^{42,43}$ Clinical findings suggests that spiradoline produces side-effects such as dysphoria, sedation and diuresis at doses lower than those required for antinociceptive actions. The adverse effects of KOR agonists have restricted their efficient clinical use. Nevertheless, it has been suggested that KOR agonists may have neuroprotective activity through their capacity to prevent glutamat release.

The superiority of the KOR opioid agonists over other opioid agonists is that they do not produce respiratory distress. It has been shown that KOR agonists indicate an anti-opioid activity decreasing analgesia produced by MOR opioid agonists. This anti-opioid activity is produced by a different distribution of KORs on primary neurons located within the nucleus raphe magnus (NRM). The signal from the NRM neurons creates part of the descending inhibitory control pathway acting to suppress pain transmission. The NRM consists of two type neurons (primary and secondary neurons) whose axons terminate in the dorsal horn of spinal cord. It is indicated that secondary neuron discharging induces pain transmission, while primary neurons block it. ${ }^{44}$ Analgesia produced by exogenously applied opioids is principally through agonist actions at the MOR. It has been suggested that MORs are localized just at secondary cells of the NRM. Inhibition of the secondary neurons owing to MOR activation results in inhibition of GABA-ergic input to primary neurons and causes their disinhibition. Thus, inhibition of the primary neurons, which equates to their stimulation, is concluded analgesia produced in the spinal cord. KORs are localized solely on the primary neurons in the spinal cord and the anti-nociceptive effect of KOR agonists is caused by blocking the primary neurons. ${ }^{44}$ 


\section{Nociceptin Orphanin FQ Receptor (NOR)}

The NOR opioid receptor is a member of the opioid receptors subfamily whose native ligand is a peptide known as nociceptin (N/OFQ). This nociceptin opioid receptor performs same actions to those of the usual opioids resulting in inhibition of neurotransmitter release and reduced neuronal excitability. This member of the opioid receptors is involved in the regulation of many midbrain activities, especially pain transmission, feeding, memory, learning, stress and anxiety. ${ }^{45}$

The NOR acts as a dopamine endogenous antagonist that may act either by the blocking GABA or directly on dopamine to affect dopamine levels. NOR has been shown to have a hyperalgesic or anti-analgesic effect. NOR agonists produce pronociceptive effects when applied supraspinally. However, spinally NOR agonists cause analgesia at high doses. Anti-analgesic action of NOR agonists is the hypothesised cause for the supraspinal hyperalgesic effect, inhibiting endogenous opioid tone. Anti-opioid effect of NOR is produced by NOR localization on primary neuron cells of the NRM. ${ }^{46}$

Studies suggest that the levels of nociceptin in neuron cells of NRM may act to set threshold to pain, as NOR antagonist agents have been suggested to give enhance to a permanent antinociception. NOR antagonists may have a probable future as new antinociceptive drug or may be used as an adjuvant to decrease the opioid drug dose required to analgesic actions.

\section{OPIOID TOLERANCE MECHANISMS}

Opioid tolerance is defined as a shift to the right in the dose-response curve in pharmaceutical science. In other words, an increasing dose is required long time to protect the similar level of antinociception. Sometimes, chronic diseases and cancers are the reasons for higher dose of opioid requirements. ${ }^{47}$ Pharmacokinetic and pharmacodynamic changes cause the increase of opioid drug dose. Pharmacokinetic changes involve in alterations the rate of excretion from the body via the effects that modify metabolic activity of drugs. Metabolic enzyme induction results in a progressive decrease in serum levels of drug meanwhile the daily opioid dose remains constant. However, pharmacodynamic tolerance occurs when a decrease in effects of opioid drugs and express drug-activated alterations in the response of the neural systems. ${ }^{2}$

There are two major theories about the mechanisms of opioid tolerance. The first theory presents that opioid receptors undergo alterations that result in decreased receptor activation, with chronic exposure to opioid drugs. The supporting document indicates that the downregulation of opioid receptor is at least partly liable for the development of tolerance to opioid analgesia. The desensitization mechanism of opioids includes the physiological alterations of the opioid receptors. ${ }^{48}$
Heterotrimeric $G$ protein is activated, when the opioid drug is bound to its receptor. Eventually, activation of $\mathrm{G}$ proteins causes attenuating excitability throughout the neuron membranes in the nociceptive pathways. This effect is formed via a reduction in cyclic adenosine monophosphate (cAMP), leading to a repression of $\mathrm{Ca}^{2+}$ and $\mathrm{Na}^{+}$channels and resulting in antinociception (Figure 1). Long time, changes in the mechanism of $G$ protein pathway may lead to attenuated antinociception via opioid receptor desensitization. ${ }^{49,50}$ In experimental studies, the desensitization arises when enzymes or cellular regulatory proteins, such as adenylyl cyclase, $\beta$ arrestins, and GPCR kinases are activated by opioids in such a way that they decouple $G$ protein from the opioid receptor in the cell membrane later reducing antinociceptive effect. Before this, opioid analgesic tolerance has been associated with opioid receptor desensitization in rats. However, actual reviews emphasize how much is left to be learned about these complex intracellular tolerance mechanisms. ${ }^{49,51}$ There is substantial evidence indicating that application of a mitogen-activated protein kinase (MAPK) inhibitor reduces morphine analgesic tolerance. ${ }^{52}$

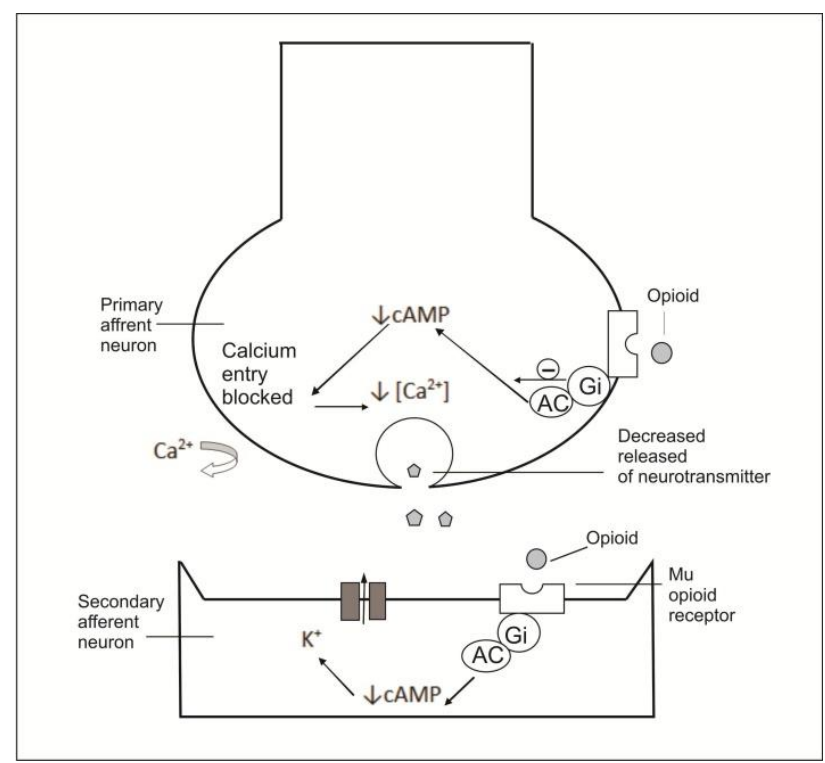

When the opioid is bound to the receptor, the connected $G$ protein becomes activated. Activation of $G$ proteins finally leads to decreasing excitability along the cell membranes of neurons in the pain pathways. This action occurs via a reduction in cyclic adenosine monophosphate (cAMP), leading to a repression of $\mathrm{Na}+$ and $\mathrm{Ca} 2+$ channels and resulting in antinociception.

Figure 1: The action mechanism of opioid receptors. Opioid receptors belong to the family of $\mathrm{G}$ proteincoupled receptors (GPCRs).

The second mechanism of opioid analgesic tolerance is performed through internalization of the opioid receptor from the bilayer lipid membrane of cell. The opioid receptors density situated on the nerve cell membrane is administered by endocytic mechanism. Once entered into the nerve cells the opioid receptor can no longtime 
activity and is rapidly down-regulated. It is prevented the development of opioid analgesic tolerance in $\beta$-arrestin2 (a down-regulators) deficient rats and continue to have sustained opioid analgesia. ${ }^{53}$ Nevertheless, numerous studies have indicated that enhanced internalization may essentially attenuated opioid tolerance by getting desensitized receptors off the membrane and leading to resensitization via recycled receptors being displaced. ${ }^{54}$

Different opioid receptor agonist drugs have been indicated to distinct in their ability to down-regulate or desensitize opioid receptors. ${ }^{55}$ One of these differences has been based on the intrinsic activity of the opioid agonist drugs. Every opioid has a given level of intrinsic activity for the different opioid receptors. Intrinsic activity is a notional parameter that pertains the number of receptors engaged to the size of the opioid receptor response. It is required to retain a number of receptors out of the all population to create a given effect. ${ }^{56}$ The number of receptors that need to be occupied to generate an antinociceptive action is supposed to be reverse proportional to the intrinsic efficacy. ${ }^{57,58}$

Generally, chronic treatment with morphine has been known to cause a greater rightward shift in dose response curve with lower intrinsic activity. ${ }^{59}$ Experimental models have suggested that long-term treatment with high activity opioids, such as fentanyl, that have a important receptor stock and down-regulate a little receptors. ${ }^{58}$ At the same time, the evidences indicate high activity opioids virtually activate more $G$ protein coupled receptor kinases than low activity opioids. ${ }^{60}$ On the other hand, animal studies suggest that melanocortin 4 receptor antagonists attenuate tolerance to morphine analgesia in rats. Melatonin is a hormone secreted by the pineal gland and inhibits morphine-induced hyperalgesia via the PKC pathway in rats. ${ }^{27}$ The endocrine hormone melatonin reverses morphine tolerance by inhibiting microglia activation and HSP27 expression. ${ }^{61}$ The orexin 1 receptor is intensely lokalized the hypothalamus and regulates appetite. Blockade of orexin type 1 receptors prevents the development of morphine analgesic tolerance in the brainstem. $^{62}$

\section{SEROTONIN RECEPTORS}

The serotonin (5-hydroxytryptamine, 5-HT) is a monoamine neurotransmitter and biochemically derived from the amino acid tryptophan and one of the most ancient signaling molecules. 5-HT is localized in various cell types, such as enterochromaffin cells and blood platelets and the central nervous system cells. ${ }^{63} 5$-HT is an important regulator of a wide variety of behaviors such as feelings of well-being and happiness. ${ }^{64}$

The 5-HT receptors are located on the cell membrane of nerve cells and a family of $\mathrm{G}$ protein-coupled receptors (GPCRs). With the exception of the 5-HT3, these receptors are a ligand-gated ion channels and found in the peripheral and central neurons. ${ }^{65,66}$ The 5-HT receptors are divided into seven different classes $\left(5-\mathrm{HT}_{1}\right.$ to $\left.5-\mathrm{HT}_{7}\right)$ according to their structural and transmission characteristics (Table 2). These receptors intercede both inhibitory and excitatory neurotransmission in neuronal circuits. The membrane 5-HT receptors are activated by the 5-HT molecule, which modulates the release of many neurotransmitters and hormones, including epinephrine, GABA, dopamine, acetylcholine, cortisol, prolactin, substance $\mathrm{P}$, oxytocin and vasopressin. ${ }^{67}$ Furthermore, the 5-HT receptors regulate different neurological and physiological processes such as appetite, aggression, mood, anxiety, cognition, learning, memory, nausea, thermoregulation and sleep. At the same time, these receptors are the target of a diversity of biochemical drugs, including several antipsychotics, antidepressants, antiemetics, gastroprokinetic, hallucinogens and antimigraine agents. ${ }^{64}$

Table 2: Serotonin receptors subtypes.

\begin{tabular}{|llll|}
\hline Receptor Subtypes & $\begin{array}{l}\text { Signaling Mechanism } \\
\text { 5-HT }\end{array}$ Distribution & Deffects \\
\hline $5-\mathrm{HT}_{1 \mathrm{~B}}$ & $\mathrm{Gi}, \downarrow$ cAMP & $\begin{array}{l}\text { Substantia nigra, globus } \\
\text { pallidus, basal ganglia }\end{array}$ & $\begin{array}{l}\text { Reuronal inhibition, behavioral } \\
\text { changes }\end{array}$ \\
\hline $5-\mathrm{HT}_{1 \mathrm{D}}$ & $\mathrm{Gi}, \downarrow$ cAMP & Brain & Vasoconstriction \\
\hline $5-\mathrm{HT}_{1 \mathrm{E}}$ & $\mathrm{Gi}, \downarrow \mathrm{cAMP}$ & Cortex, hippocampus & Memory \\
\hline $5-\mathrm{HT}_{1 \mathrm{~F}}$ & $\mathrm{Gi}, \downarrow \mathrm{cAMP}$ & Globus pallidus, putamen & Anxiety, vasoconstriction \\
\hline $5-\mathrm{HT}_{2 \mathrm{~A}}$ & $\mathrm{Gq}, \uparrow \mathrm{IP}_{3}$ & Platelets, cerebral cortex & $\begin{array}{l}\text { Cellular excitaton, muscle } \\
\text { contraction }\end{array}$ \\
\hline $5-\mathrm{HT}_{2 \mathrm{~B}}$ & $\mathrm{Gq}, \uparrow \mathrm{IP}_{3}$ & Stomach & Appetite \\
\hline $5-\mathrm{HT}_{2 \mathrm{C}}$ & $\mathrm{Gq}, \uparrow \mathrm{IP}_{3}$ & Hippocampus, substantia nigra & Anxiety \\
\hline $5-\mathrm{HT}_{3}$ & $\mathrm{Na} \mathrm{K}^{+}$ion channel & Area postrema, enteric nerves & Vomiting \\
\hline $5-\mathrm{HT}_{4}$ & $\mathrm{Gs}, \uparrow \mathrm{cAMP}$ & Cortex, smooth muscle & Gut motility \\
\hline $5-\mathrm{HT}_{5 \mathrm{~A}, \mathrm{~B}}$ & $\mathrm{Gi}, \downarrow \mathrm{cAMP}$ & Brain & Locomotion, sleep \\
\hline $5-\mathrm{HT}_{6}$ & $\mathrm{Gs}, \uparrow \mathrm{cAMP}$ & Brain & Cognition, learning \\
\hline $5-\mathrm{HT}_{7}$ & $\mathrm{Gs}, \uparrow \mathrm{cAMP}$ & Brain & Mood, memory, sleep \\
\hline
\end{tabular}


The $5-\mathrm{HT}_{1}$ family includes five receptor subtypes that are largelly coupled to $\mathrm{Gi}$ proteins and inhibit adenylate cyclase enzyme. 5- $\mathrm{HT}_{1}$ receptor subtypes are highly localized in the hippocampus, basal ganglia and raphe nuclei. The $\mathrm{Gq}$ protein receptor $5-\mathrm{HT}_{2}$ activate phospholipase $\mathrm{C}$ and is localized in the cortex, hippocampus, basal ganglia and medulla spinalis. ${ }^{68} 5$ $\mathrm{HT}_{4}, 5-\mathrm{HT}_{6}$, and $5-\mathrm{HT}_{7}$ receptors bind to Gs proteins and are positively associated with adenylate cyclase enzyme. The $5-\mathrm{HT}_{4}$ receptor subtypes are fundamentally expressed in the hippocampus and basal ganglia, 5- $\mathrm{HT}_{6}$ receptors in the hippocampus, amygdala, striatum and cortex, and $5-\mathrm{HT}_{7}$ receptors in the amygdala, hippocampus and hypothalamus. Besides, subtypes of the $5-\mathrm{HT}_{5}$ receptor are localized in the hypothalamus, hippocampus, cerebellum and cortex.

Finally, the 5- $\mathrm{HT}_{3}$ receptor belongs to the ligand-gated ion channels and consequently differs structurally from all other 5-HT receptors, and stimulation of this receptor leads to the opening of a cation channel such as sodium, potassium and calcium. ${ }^{69} 5-\mathrm{HT}_{3}$ receptors are highly localized in both peripherally and centrally neurons, in the substantia gelatinosa of the spinal cord, in the brainstem and cortex, and limbic areas, such as the entorhinal cortex, hippocampus and amygdala. ${ }^{68,70}$

\section{Serotonin and pain}

Serotonergic neurons are highly expressed in the raphe nuclei of the brainstem and project to the spinal cord and forebrain. The raphe nuclei of the brainstem are divided in two groups structurally and functionally. The rostral group of raphe includes median raphe nucleus (MRN) and dorsal raphe nucleus (DRN). In addition, the caudal group comprises the raphe pallidus and the nucleus raphe magnus (NRM). ${ }^{71}$ The afferent fibers to the raphe nuclei originate from the hypothalamus, limbic system, and

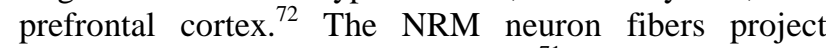
mainly to the spinal cord dorsal horn. ${ }^{71}$

It has been well established that 5-HT producing neurons contribute to descending pain control pathways. ${ }^{73,74}$ Experimental studies suggest that this pain control pathways derived from the raphe nuclei have a significant role in serotonergic pain regulation. ${ }^{75}$ Neurons in the rostralventromedial medulla (RVM), give arise to significant facilitatory and inhibitory serotonergic projections. These serotonergic neurons continue in the dorsolateral funiculus and terminate usually in the dorsal horn neurons in laminas I, II, IV and V in spinal cord. ${ }^{76}$ Injections of 5-HT-receptor agonists into the spinal cord have shown inhibitory and facilitatory activity on the pain behavior in animals. Systemic administration of 5-HT mostly decreases nociceptive transmission and pain behavior in experimental animals. ${ }^{77}$ Excitatory effects have also been reported, mediated via $5-\mathrm{HT}_{7}$ receptors, and possibly caused by increases in cyclic AMP levels. ${ }^{78}$ Neuronal 5-HT receptors are highly localized on primary afferent neuron terminals, excitatory and inhibitory interneurons in the spinal cord. 5- $\mathrm{HT}_{1 \mathrm{~A}}$ and $5-\mathrm{HT}_{1 \mathrm{~B}}$ receptors are present at high densities in dorsal horn neurons, for example on wide dynamic range (WDR) neurons. Activated 5- $\mathrm{HT}_{1 \mathrm{~A}}$ receptors cause opening of $\mathrm{K}^{+}$ and a closing of $\mathrm{Ca}^{2+}$ channels through coupling negatively to adenylate cyclase. Their activation should thus directly hyperpolarize substantia gelatinosa neurons and produce an inhibitory effect on the pain transmission. ${ }^{79} 5-\mathrm{HT}_{2}$ receptors are positively coupled to phospholipase $\mathrm{C}$, and thus exert excitatory influences on neuronal activity. The antinociceptive effects of $5-\mathrm{HT}_{2 \mathrm{~A}}$ subtype would have to be caused by the activation of inhibitory interneurons. ${ }^{80}$ The ionotropic $5-\mathrm{HT}_{3}$ receptor increases neuronal excitability, and has been found to mediate descending facilitation through serotonergic pathways. In accordance, ondansetron (5-HT 3 antagonist) decreases pain transmission onto nociceptive stimuli after nerve cell damage in rats. ${ }^{81}$ In the animal model, it has been suggested that $5-\mathrm{HT}_{1 \mathrm{~B}}, 5-\mathrm{HT}_{2} \mathrm{C}, 5-\mathrm{HT}_{3}$ and $5-\mathrm{HT}_{4}$ receptors are involved in serotonin mediated analgesia. ${ }^{82}$

The central nociceptive control system is arrenged by in the periaqueductal grey (PAG) neurons. The PAG is a crucial section and includes several pain control activity. ${ }^{74}$ Various pain stimuli activates the serotonergic neurons in the RVM and enhances 5-HT release in the spinal cord. Additionally, the serotonergic neurons in the medial and dorsal raphe nuclei have also been shown to be substantial in pain control mechanism. ${ }^{76}$ The evidences suggest that the ascending serotoninergic neurons might also support to pain regulation by different mechanism. ${ }^{83}$ In addition, some evidence indicates that cortical 5-HT receptors are involved in descending pain regulation. ${ }^{84}$

Several studies indicate that spinal 5-HT receptors have antinociceptive effect, pronociceptive effect or no effect. ${ }^{77,85,86}$ Exactly, this demonstrates that distinct areas and distinct proportions of 5-HT receptors could explain in different ways for the regulation of nociception. Intrathecally administered WAY $100635 \quad\left(5-\mathrm{HT}_{1 \mathrm{~A}}\right.$ receptor antagonist) with sub-effective doses of 5-HT increases the analgesia in the paw pressure test in rats. Conversely, WAY 100635 deactivates the analgesic effect in the formalin test, an animal pain model. ${ }^{87}$ In addition, the evidences suggest that intrathecal administration of $8-\mathrm{OH}-\mathrm{DPAT}$ (5- $\mathrm{HT}_{1 \mathrm{~A}}$ receptor agonist) creates antinociception in the formalin test and pronociception in the paw pressure pain test. ${ }^{88}$ On the other hand, dysfunction in the central serotonin systems increases pain sensations. ${ }^{89}$ The antipsychotic and serotonin $5-\mathrm{HT}_{1 \mathrm{~A}}$ receptor agonist aripiprazole induces antinociceptive effects. ${ }^{90}$ Recently, it has been reported that tegaserod, a 5- $\mathrm{HT}_{4}$ receptor agonist, modulate visceral pain transmission. Tegaserod activates supraspinal $5-\mathrm{HT}_{4}$ receptors which initiates the release of opioids at supraspinal site. Subsequently, opioids activate descending noradrenergic pathways to the spinal cord, and produce analgesia. ${ }^{91}$ Intraperitoneal administration duloxetine (a 5-HT reuptake inhibitors) inhibits postoperative pain by increasing spinal 5-HT levels and 
activating spinal $5-\mathrm{HT}_{2 \mathrm{~A}}$ receptor. ${ }^{92}$ Nefopam is a nonopioid analgesic drug, used to control postoperative pain. Intrathecal nefopam is effective in the attenuation of neuropathic pain and nefopam increases the level of 5$\mathrm{HT}$. In addition, the $5-\mathrm{HT}_{7}$ receptors involve in the antinociceptive action of nefopam in the spinal cord. ${ }^{93}$ Furthermore, an animal pain model suggests that spinal neuron $5-\mathrm{HT}_{5 \mathrm{~A}}$ receptors are involve in 5-HT-induced analgesia in rats. ${ }^{94}$

\section{Serotonin receptors and opioid antinociceptive tolerance}

Numerous electrophysiological and behavioral studies have shown an interaction of the serotonergic system and morphine analgesia. Serotonergic pathways are thought to be functionally distinct from but to interact with the opioid-mediated pain modulatory circuit. ${ }^{95} 5-\mathrm{HT}$ in the NRM may be necessary for the action of morphine. ${ }^{96}$ Morphine has direct actions at the $5-\mathrm{HT}_{3}$ receptor, suppressing 5-HT-induced currents in neurons in a competitive way. $^{97}$ Administered systemic morphine produce analgesia mediated by $5-\mathrm{HT}_{7}$ receptors in the spinal cord in mice. ${ }^{98}$ It has been also reported that between the serotonergic and GABAergic systems involve the interactions in opioid analgesia. ${ }^{99}$ Acute administration of morphine increases the release of 5-HT principally from projection areas of the DRN and MRN. ${ }^{100}$ However, chronic administration of morphine reduces the release of 5-HT from the serotonergic nerve terminals. $^{101}$

Various experimental studies have suggested that descending inhibition of pain transmission by the morphine depends on central serotonergic neurons. ${ }^{102,103}$ The midbrain serotonergic system is a necessary constituent of the central nociceptive regulatory circuitry mediating opioid analgesic effect. $\mathrm{Lmx} 1 \mathrm{~b}^{\mathrm{f} / \mathrm{f} / \mathrm{p}}$ mice which lack supraspinal serotonergic neurons have no antinociceptive effect after administration of a kappa opioid receptor agonist at supraspinal and spinal locations. ${ }^{104}$ Interestingly, tramadol, a drug successfully used in pain management, acts through a combination of $\mu$-pioid receptor and 5- $\mathrm{HT}_{1 \mathrm{~A}}$ receptors. ${ }^{105}$ Opioids produce their antinociceptive effect partly via activation on central serotonergic neurons. ${ }^{106}$ Systemic administration of morphine causes the release of 5-HT in different brainstem locations and the spinal cord dorsal horn. ${ }^{21,107}$ Though the mechanism of morphine stimulated the 5-HT release remains obscure, it has been shown the involvement of excitatory neurotransmitter and GABA. ${ }^{100,106}$ Furthermore, 5- $\mathrm{HT}_{1 \mathrm{~A}}$ and $5-\mathrm{HT}_{1 \mathrm{~B}}$ receptors are involved in regulation spinal pain transmission, and morphine analgesia could be inhibited by administration of either mianserin (a 5- $\mathrm{HT}_{1 \mathrm{C}}$ antagonist) or spiperone (a $5-\mathrm{HT}_{1 \mathrm{~A}}$ antagonist). ${ }^{108,109}$ These findings indicate a complex interaction between opioid action and 5-HT receptor subtypes in the spinal cord.
Different types of serotonin receptors show different effects on morphine analgesia. Administration of morphine stimulates the release 5-HT in the spinal cord neurons and the increase in 5-HT supports morphine analgesia normally but reduces that via spinal $5-\mathrm{HT}_{3}$ receptor subtypes in neuropathic pain model. ${ }^{110}$ The 5$\mathrm{HT}_{7}$, a subtype of serotonin receptor, play a significant role in mediating opioid and non-opioid type stress analgesia. $^{111}$ Surprisingly, repeated administration of fluoxetine reduces morphine antinociception in hypertensive and normal rats. ${ }^{112}$ It has been reported that blockade of $5-\mathrm{HT}_{7}$ receptors inhibit the opioid analgesia. $^{113}$ In addition, evidences indicate that the activation 5- $\mathrm{HT}_{7}$ receptors decrease morphine withdrawal. ${ }^{114}$ Further, coadministration of maprotiline (5-HT re-uptake inhibitor) increases the morphine analgesia by 4 -fold in rats. ${ }^{115}$

Spinal and supraspinal serotonergic neurons may also play a pathophysiological role in the development of tolerance to morphine. For example, coadministration of fluoxetine, amitriptyline and zimelidine (selective 5-HT uptake inhibitors) with morphine prevents the morphine analgesic tolerance. ${ }^{17,116}$ Conversely, administered with either 1-tryptophan, the 5-HT precursor, accelerates the development of morphine tolerance. ${ }^{117}$ These conflicting findings could probable caused by a distinct in 5-HT density in different synapses. These conflicting findings could also be owing to the distinct projections of 5-HT neurons arised from either the MRN or the raphe magnus. Administrated of 5- $\mathrm{HT}_{1 \mathrm{~A}}$ receptor agonist 8-OH-DPAT to dorsal raphe nucleus attenuated morphine analgesic tolerance, however administrated of the similar doses of 8-OH-DPAT to the median raphe nucleus did not change morphine analgesic tolerance. ${ }^{23}$ The activation of $5-\mathrm{HT}_{1 \mathrm{~A}}$ receptors causes a varied level of neuroprotection in distinct experimental models of nerve cell damage. Therefore, injection of 8-OH-DPAT inhibits morphineinduced apoptosis dorsal raphe nucleus and attenuates morphine tolerance in rats. ${ }^{25}$ Recent experimental studies suggest that the $5-\mathrm{HT}_{3}$ receptor participates in opioid antinociceptive tolerance. Unlike other receptors, 5- $\mathrm{HT}_{3}$ receptor subtype is a ligand-gated ion channel including five monomers which form a structure centrally permeable to positive ions. The $5-\mathrm{HT}_{3}$ antagonist ondansetron administered with morphine prevents morphine tolerance in mice. ${ }^{118}$ In mice with skin cancer, $5-\mathrm{HT}_{1 \mathrm{~A}}$ receptor partial agonist buspiron reduces tolerance to analgesic effect of morphine. ${ }^{119}$ After activation of the 5- $\mathrm{HT}_{2 \mathrm{~A}}$ receptor, administrated of 5-HT with morphine results in receptor internalization, downregulation and desensitization of the opioid receptor. ${ }^{120}$

\section{CONCLUSION}

The mechanisms of opioid analgesic tolerance are not yet exactly understood, although the existence of a great number of information on the subject. Opioid tolerance is a complicated phenomenon mediated by different cellular and behavioral alterations. Several factors can cause the 
development of tolerance to morphine. These factors include down-regulation of opioid receptors, desensitization of G-proteins, altered intracellular signaling and postreceptor neural events. Serotonin receptor system plays a pathophysiological role in the development tolerance to opioid analgesia. Until now, several studies indicate that 5 -HT receptor subtypes produce diverse effects on opioid tolerance.

On the other hand, analgesic tolerance is a restricting factor along opioid therapy in clinical application. Patients should be given security that morphine analgesic tolerance is not a serious problem and that morphine will maintain to relieve their chronic pain for several years. Therefore, the capability to control the tolerance process is a neccesary step in designing suitable pharmacologic method for the treatment of persistent chronic pain. Serotonin receptor agonist or antagonist drugs can be minimized by the development of opioid tolerance.

\section{ACKNOWLEDGEMENT}

This study was supported by Cumhuriyet University Scientific Research Project (T-329, CUBAP, Sivas, Turkey).

Funding: No funding sources Conflict of interest: None declared

Ethical approval: Not required

\section{REFERENCES}

1. Morgan MM, Christie MJ. Analysis of opioid efficacy, tolerance, addiction and dependence from cell culture to human. $\mathrm{Br} \mathrm{J}$ Pharmacol. 2011;164:1322-34.

2. Dumas EO, Pollack GM. Opioid tolerance development: a pharmacokinetic /pharmacodynamic perspective. The AAPS Journal. 2008;10(4):537-51.

3. Cox BM. Drug tolerance and physical dependence; in Wall PD, Taylor P (eds): Principles of Drug Action: The Basis of Pharmacology. New York, ChurchillLivingstone, 1990:639-690.

4. Foley K. Changing concepts of tolerance to opioids: what the cancer patient has taught us. In $\mathrm{C}$. R.Chapman and K. M. Foley (Eds.), Current and emerging issues in cancer pain: research and practice. New York: Raven Press; 1993:331-350.

5. Nestler EJ, Aghajanian GK. Molecular and cellular basis of addiction. Science 1997;278:58-63.

6. Vanderah TW, Suenaga NM, Ossipov MH, Malan TP, Lai J, Porreca F. Tonic descending facilitation from the rostral ventromedial medulla mediates opioid-induced abnormal pain and antinociceptive tolerance. J Neurosci. 2001;21:279-86.

7. Burgess SE, Gardell LR, Ossipov MH, Malan TP, Vanderah TW, Lai J, et al. Time-dependent descending facilitation from the rostral ventromedial medulla maintains, but does not initiate, neuropathic pain. J Neurosci. 2002;22:5129-36.
8. Ozdemir E, Bagcivan I, Durmus N, Altun A, Gursoy S. The nitric oxide-cGMP signaling pathway plays a significant role in tolerance to the analgesic effect of morphine. Can J Physiol Pharmacol. 2011a;89:89-95.

9. Durmus N, Bagcivan I, Ozdemir E, Altun A, Gursoy S. Soluble guanylyl cyclase activators increase the expression of tolerance to morphine analgesic effect. Bratisl Lek Listy. 2014;115(6):334-9.

10. Williams JT, Christie MJ, Manzoni O. Cellular and synaptic adaptations mediating opioid dependence. Physiol Rev. 2001;81:299-343.

11. Xin L, Geller EB, Liu-Chen LY, Chen C, Adler MW. Substance $\mathrm{P}$ release in the rat periaqueductal gray and preoptic anterior hypothalamus after noxious cold stimulation: effect of selective mu and kappa opioid agonists. J Pharmacol Exp Ther. 1997;282:1055-63.

12. Gardell LR, Wang R, Burgess SE. Sustained morphine exposure induces a spinal dynorphindependent enhancement of excitatory transmitter release from primary afferent fibers. J Neurosci. 2002;22:6747-55.

13. Wong CS, Hsu MM, Chou R, Chou YY, Tung CS. Intrathecal cyclooxygenase inhibitor administration attenuates morphine antinociceptive tolerance in rats. Br J Anaesth. 2000;85(5):747-51.

14. Ozdemir E, Bagcivan I, Gursoy S. Modulation of morphine analgesia and tolerance in rats by NMDA receptor antagonists. Neurophysiology. 2012;44:12330.

15. Kellstein DE, Mayer DJ. Spinal co-administration of cholecystokinin antagonists with morphine prevents the development of opioid tolerance. Pain. 1991;47:221-9.

16. Ozdemir E, Bagcivan I, Gursoy S, Altun A, Durmus N. Effects of fluoxetine and LY 365265 on tolerance to the analgesic effect of morphine in rats. Acta Physiologica Hungarica. 2011;98(2):205-13.

17. Ozdemir E, Gursoy S, Bagcivan S. The effects of serotonin/norepinephrine reuptake inhibitors and serotonin receptor agonist on morphine analgesia and tolerance in rats. Journal of Physiological Science. 2012;62:317-23.

18. Zhang $\mathrm{ZH}$, Yang SW, Chen JY. Interaction of serotonin and norepinephrine in spinal antinociception. Brain Res Bull. 1995;38:167-71.

19. Yaksh TL, Wilson R. Spinal serotonin terminal system mediates antinociception. J Pharmacol Exp Ther. 1979;208:446-53.

20. Schul R, Frenk H. The role of serotonin in analgesia elicited by morphine in the periaqueductal gray matter. Brain Res. 1991;556:353-7.

21. Grauer SM, Tao R, Auerbask SB. Morphine induces an increase in extracellular serotonin in the rat diencephalon. Brain Res. 1992;599:277-82.

22. Tao R, Ma Z, Auerbach SB. Alteration in regulation of serotonin release in rat dorsal raphe nucleus after prolonged exposure to morphine. J Pharmacol Exp Ther. 1998;286:481-8.

23. Nayebi ARM, Charkhpour M. Role of 5-HT1A and 5-HT2 receptors of dorsal and median raphe nucleus 
in tolerance to morphine analgesia in rats. Pharmacol Biochem Behav. 2006;83:203-7.

24. Li JY, Wong CH, Huang EY, Lin YC, Chen YL, Tan $\mathrm{PP}$, et al. Modulations of spinal serotonin activity affect the development of morphine tolerance. Anesth Analg. 2001;92:1563-68.

25. Charkhpour M, Nayebi ARM, Doustar Y, Hassanzadeh K. 8-OH-DPAT prevents morphineinduced apoptosis in rat dorsal raphe nucleus: a possible mechanism for attenuating morphine tolerance. Anesth Analg. 2010;111:1316-21.

26. Janecka A, Fichna J, Janecki T. Opioid receptors and their ligands. Curr Top Med Chem. 2004;4(1):1-17.

27. Bodnar RJ. Endogenous opiates and behavior: 2013. Peptides. 2014;62:67-136.

28. Mollereau C, Parmentier M, Mailleux P. ORL1, a novel member of the opioid receptor family: cloning, functional expression and localization. FEBS Lett. 1994;341(1):33-8.

29. Stein C, Schäfer M, Machelska H. Attacking pain at its source: new perspectives on opioids. Nat Med. 2003;9(8):1003-8.

30. Waldhoer M, Bartlett SE, Whistler JL. Opioid receptors. Annu Rev Biochem. 2004;73:953-90.

31. Garzon J, Jen M, Sanchez-Blazquez P, Lee N. Dynorphin (1-13), a long-lasting inhibitor of opiate receptor binding in vitro. Life Sci. 1982;31:1789-92.

32. Ananthan S. Opioid ligands with mixed mu/delta opioid receptor interactions: an emerging approach to novel analgesics. AAPS J. 2006;8(1):E118-25.

33. Gackenheimer SL, Suter TM, Pintar JE. Localization of opioid receptor antagonist [3H]-LY255582 binding sites in mouse brain: comparison with the distribution of mu, delta and kappa binding sites. Neuropeptides. 2005;39(6):559-67.

34. Pasternak GW. Opioids and their receptors: Are we there yet? Neuropharmacology. 2014;76:198-203.

35. Hack SP, Vaughan CW, Christie MJ. Modulation of GABA release during morphine withdrawal in midbrain neurons in vitro. Neuropharmacology. 2003;45:575-84.

36. Vella-Brincat J, Macleod AD. Adverse effects of opioids on the central nervous systems of palliative care patients. J Pain Palliat Care Pharmacother. 2007;21(1):15-25.

37. Feng Y, He X, Yang Y, Chao D, Lazarus LH, Xia Y. Current research on opioid receptor function. Curr Drug Targets. 2012;13(2):230-46.

38. Mogil JS, Grisel JE. Transgenic studies of pain. Pain. 1998;77:107-28.

39. Akil H, Owens C, Gutstein H, Taylor L, Curran E, Watson S. Endogenous opioids: overview and current issues. Drug Alcohol Depend. 1998;51(1-2):127-40.

40. Lutz PE, Kieffer BL. Opioid receptors: distinct roles in mood disorders. Trends Neurosci. 2013;36(3):195206.

41. Lawrence DM, Bidlack JM. The kappa opioid receptor expressed on the mouse R1.1 thymoma cell line is coupled to adenylyl cyclase through a pertussis toxin-sensitive guanine nucleotide-binding regulatory protein. J Pharmacol Exp Ther. 1993;266(3):1678-83.

42. Wadenberg ML. A review of the properties of spiradoline: a potent and selective kappa-opioid receptor agonist. CNS Drug Rev. 2003;9:187-98.

43. Walsh SL, Strain EC, Abreu ME, Bigelow GE, Wadenberg ML. Enado line, a selective kappa opioid agonist: comparison with butorphanol and hydromorphone in humans, a review of the properties of spiradoline: a potent and selective kappa-opioid receptor agonist. Psychopharmacology (Berl). 2001;157:151-62.

44. Bie B, Pan ZZ. Presynaptic mechanism for antianalgesic and anti-hyperalgesic actions of kappaopioid receptors. J Neurosci. 2003;13:23(19):7262-8.

45. Toll L, MR Bruchas, G Calo, BM Cox, NT Zaveri. Nociceptin/orphanin FQ receptor structure, signaling, ligands, functions, and interactions with opioid systems. Pharmacol Rev. 2016;68(2):419-57.

46. Pan Z, Hirakawa N, Fields HL. A cellular mechanism for the bidirectional pain-modulating actions of orphanin FQ/nociceptin. Neuron. 2000;26:515-22.

47. Collin E, Poulain P, Gauvain-Piquard A, Petit G, Pichard-Leandri E. Is disease progression the major factor in morphine "tolerance" in cancer pain treatment? Pain. 1993;55:319-26.

48. Dang VC, Christie MJ. Mechanisms of rapid opioid receptor desensitization, resensitization and tolerance in brain neurons. Br J Pharmacol. 2012;165(6):170416.

49. Raehal KM, Bohn LM. Mu opioid receptor regulation and opiate responsiveness. AAPS Journal. 2005; 7:E587-91.

50. Wang HY, Friedman E, Olmstead MC, Burns LH. Ultra-low-dose naloxone suppresses opioid tolerance, dependence and associated changes in mu opioid receptor- $\mathrm{G}$ protein coupling and $\mathrm{G}$ beta gamma signaling. Neuroscience. 2005;135;247-61.

51. Sim LJ, Selley DE, Dworkin SI, Childers SR. Effects of chronic morphine administration on mu opioid receptor-stimulated [35S] GTP gammaS autoradiography in rat brain. Journal of Neuroscience. 1996;16:2684-92.

52. Chen Y, Sommer C. The role of mitogen-activated protein kinase (MAPK) in morphine tolerance and dependence. Mol Neurobiol. 2009;40:101-7.

53. Bohn LM, Lefkowitz RJ, Caron MG. Differential mechanisms of morphine antinociceptive tolerance revealed in (beta) arrestin-2 knock-out mice. Journal of Neuroscience. 2002;22:10494-500.

54. Finn AK, Whistler JL. Endocytosis of the mu opioid receptor reduces tolerance and a cellular hallmark of opiate withdrawal. Neuron. 2001;32:829-39.

55. Sim-Selley LJ, Selley DE, Vogt LJ, Childers SR, Martin TJ. Chronic heroin self-administration desensitizes mu opioid receptor-activated G-proteins inspecific regions of rat brain. Journal of Neuroscience. 2000;20:4555-62. 
56. Mercadante S. Opioid rotation for cancer pain: rationale and clinical aspects. Cancer. 1999;86:185666.

57. Duttaroy A, Yoburn BC. The effect of intrinsic efficacy on opioid tolerance. Anesthesiology. 1995;82:1226-36.

58. Sosnowski M, Yaksh TL. Differential crosstolerance between intrathecal morphine and sufentanil in the rat. Anesthesiology. 1990;73:1141-47.

59. Saeki S, Yaksh TL. Suppression of nociceptive responses by spinal mu opioid agonists: effects of stimulus intensity and agonist efficacy. Anesthesia \& Analgesia. 1993;77:265-74.

60. Terman GW, Jin W, Cheong YP. G-Protein receptor kinase 3 (GRK3) influences opioid analgesic tolerance but not opioid withdrawal. British Journal of Pharmacology. 2004;141:55-64.

61. Lin SH, Huang YN, Kao JH, Tien LT, Tsai RY, Wong CS. Melatonin reverses morphine tolerance by inhibiting microglia activation and HSP27 expression. Life Sci. 2016;152:38-43.

62. Ghaemi-Jandabi M, Azizi H, Semnanian S. Blockade of orexin type 1 receptors inhibits the development of morphine tolerance in lateral paragiganto-cellularis nucleus: an electrophysiological approach. Brain Res. 2014;1578:14-22.

63. Cooper JR, Bloom FE, Roth RH. The Biochemical Basis of Neuropharmacology, 8th ed. Oxford University Press, New York, USA; 2003:338-344.

64. Nichols DE, Nichols CD. Serotonin receptors. Chem Rev. 2008;108(5):1614-41.

65. Hoyer D, Clarke DE, Fozard JR. International Union of Pharmacology classification of receptors for 5hydroxytryptamine (Serotonin). Pharmacol Rev. 1994;46:157-203.

66. Björk K, Sjögren B, Svenningsson P. Regulation of serotonin receptor function in the nervous system by lipid rafts and adaptor proteins. Experimental Cell Research. 2010;316:1351-6.

67. Hannon J, Hoyer D. Serotonin receptors and systems: endless diversity? Acta Biol Szeged. 2002;46(1-2):112 .

68. Barnes NM, Sharp T. A review of central 5-HT receptors and their function. Neuropharmacology. 1999;38:1083-152.

69. Hoyer D, Hannon JP, Martin GR. Molecular, pharmacological and functional diversity of 5-HT receptors. Pharmacol Biochem Behav. 2002;71:53354.

70. Palacios JM, Waeber C, Hoyer D, Mengod G. Distribution of serotonin receptors. Ann NY Acad Sci. 1990;600:36-52.

71. Hornung JP. The human raphe nuclei and the serotonergic system. J Chem Neuroanat. 2003;26:331-43.

72. Jacobs BL, Azmitia EC. Structure and function of the brain serotonin system. Physiol Rev. 1992;72(1):165229.

73. Zhao ZQ, Gao YJ, Sun YG, Zhao CS, Gereau RW, Chen ZF. Central serotonergic neurons are differentially required for opioid analgesia but not for morphine tolerance or morphine reward. PNAS. 2007;104(36):14519-24.

74. Fields HL, Basbaum AI, Heinricher MH. Central nervous system mechanisms of pain modulation. In: McMahon SB, Koltzenburg M (eds). Wall and Melzack's textbook of pain. 5th ed. Elsevier, China; 2006:125-42.

75. Lopez-Garcia JA. Serotonergic modulation of spinal sensory circuits. Curr Top Med Chem. 2006;6:198796.

76. Millan MJ. Descending control of pain. Prog Neurobiol. 2002;66:355-474.

77. Hains BC, Willis WD, Hulsebosch CE. Serotonin receptors 5-HT1A and 5-HT3 reduce hyperexcitability of dorsal horn neurons after chronic spinal cord hemisection injury in rat. Exp Brain Res. 2003;149:174-86.

78. Rocha-Gonzalez HI, Meneses A, Carlton SM, Granados-Soto V. Pronociceptive role of peripheral and spinal 5-HT7 receptors in the formalin test. Pain. 2005;117:182-92.

79. Zhang Y, Yang Z, Gao X, Wu G. The role of 5hydroxytryptamine1A and 5-hydroxytryptamine1B receptors in modulating spinal nociceptive transmission in normal and carrageenan-injected rats. Pain. 2001;92:201-11.

80. Sasaki M, Obata H, Saito S, Goto F. Antinociception with intrathecal alpha-methyl-5-hydroxytryptamine, a 5-hydroxytryptamine $2 \mathrm{~A} / 2 \mathrm{C}$ receptor agonist, in two rat models of sustained pain. Anesth Analg. 2003;96:1072-78.

81. Suzuki R, Rahman W, Hunt SP, Dickenson AH. Descending facilitatory control of mechanically evoked responses is enhanced in deep dorsal horn neurone following peripheral nerve injury. Brain Res. 2004;1019:68-76.

82. Jeong CY, Choi JI, Yoon MH. Roles of serotonin receptor subtypes for the antinociception of 5-HT in the spinal cord of rats. Eur $\mathrm{J}$ Pharmacol. 2004;502:205-11.

83. Wang QP, Nakai Y. The dorsal raphe: an important nucleus in pain modulation. Brain Res Bull. 1994;34:575-85.

84. Qu CL, Huo FQ, Huang FS, Li YQ, Tang JS, Jia H. The role of 5-HT receptor subtypes in the ventrolateral orbital cortex of 5-HT-induced antinociception in the rat. Neuroscience. 2008;152:487-94.

85. Mickle A, Kannampalli P, Bruckert M, Miranda A, Banerjee B, Sengupta JN. Pronociceptive effect of 5HT(1A) receptor agonist on visceral pain involves spinal N-methyl-D-aspartate (NMDA) receptor. Neuroscience. 2012;219:243-54.

86. Sasaki M, Ishizaki K, Obata H, Goto F. Effects of 5HT2 and 5-HT3 receptors on the modulation of nociceptive transmission in rat spinal cord according to the formalin test. Eur J Pharmacol. 2001;424:4552 . 
87. Bonnefont J, Chapuy E, Clottes E, Alloui A, Eschalier A. Spinal 5-HT1A receptors differentially influence nociceptive processing according to the nature of the noxious stimulus in rats: effect of WAY-100635 on the antinociceptive activities of paracetamol, venlafaxine and 5-HT. Pain. 2005; 114:482-90.

88. Bardin L, Colpaert FC. Role of spinal 5-HT(1A) receptors in morphine analgesia and tolerance in rats. Eur J Pain. 2004;8:253-61.

89. Tamano R, Ishida M, Asaki T, Hasegawa M, Shinohara S. Effect of spinal monoaminergic neuronal system dysfunction on pain threshold in rats, and the analgesic effect of serotonin and norepinephrine reuptake inhibitors. Neurosci Lett. 2016;615:78-82.

90. Almeida-Santos AF, Ferreira RC, Duarte ID, Aguiar DC, Romero TR, Moreira FA. The antipsychotic aripiprazole induces antinociceptive effects: Possible role of peripheral dopamine D2 and serotonin 5HT1A receptors. Eur J Pharmacol. 2015;765:300-6.

91. Sengupta JN, Mickle A, Kannampalli P, Spruell R, McRorie J, Shaker R, et al. Visceral analgesic effect of 5-HT(4) receptor agonist in rats involves the rostroventral medulla (RVM). Neuropharmacology. 2014;79:345-58.

92. Sun YH, Li HS, Zhu C, Hu W, Yang J, Zhao GL, et al. The analgesia effect of duloxetine on postoperative pain via intrathecal or intraperitoneal administration. Neurosci Lett. 2014;568:6-11.

93. Dam LJ, Hai L, Ha YM. Role of the 5-HT(7) receptor in the effects of intrathecal nefopam in neuropathic pain in rats. Neurosci Lett. 2014;566:50-4.

94. Muñoz-Islas E, Vidal-Cantú GC, Bravo-Hernández $\mathrm{M}$, et al. Spinal $5-\mathrm{HT}_{5} \mathrm{~A}$ receptors mediate 5-HTinduced antinociception in several pain models in rats. Pharmacol. Biochem Behav. 2014;120:25-32.

95. Fields H. State-dependent opioid control of pain. Nat Rev Neurosci. 2004;5:565-75.

96. Sounvoravong S, Nakashima MN, Wada M, Nakashima K. Decrease in serotonin concentration in raphe magnus nucleus and attenuation of morphine analgesia in two mice models of neuropathic pain. Eur J Pharmacol. 2004;484:217-23.

97. Wittmann M, Peters I, Schaaf T, Wartenberg HC, Wirz S, Nadstawek J, et al. The effects of morphine on human 5-HT3A receptors. Anesth Analg. 2006; 103:747-52.

98. Dogrul A, Seyrek M. Systemic morphine produce antinociception mediated by spinal 5-HT7, but not 5HT1A and 5-HT2 receptors in the spinal cord. Br. J. Pharmacol. 2006;149:498-505.

99. Nemmani KV, Mogil JS. Serotonin-GABA interactions in the modulation of mu- and kappaopioid analgesia. Neuropharmacology. 2003;44:30410.

100.Jolas T, Aghajanian GK. Opioids suppress spontaneous and NMDA-induced inhibitory postsynaptic currents in the dorsal raphe nucleus of the rat in vitro. Brain Res. 1997;755:229-45.
101.Jolas T, Nestler EJ, Aghajanian GK. Chronic morphine increases GABA tone on serotonergic neurons of the dorsal raphe nucleus: association with an up-regulation of the cyclic AMP pathway. Neurosciences. 2000;95:433-43.

102.Sawynok J. The role of ascending and descending noradrenergic and serotonergic pathways in opioid and non-opioid antinociception as revealed by lesion studies. Can J Physiol Pharmacol. 1989;67:975-88.

103.Marinelli S, Schnell SA, Hack SP, Christie MJ, Wessendorf MW, Vaughan CW. Serotonergic and nonserotonergic dorsal raphe neurons are pharmacologically and electrophysiologically heterogeneous. J Neurophysiol. 2004;92(6):3532-7.

104.Zhao ZQ, S Chiechio, YG Sun. Mice lacking central serotonergic neurons show enhanced inflammatory pain and an impaired analgesic response to antidepressant drugs. J Neurosci. 2007;27:6045-53.

105.Berrocoso E, De Benito MD, Mico JA. Role of serotonin 5-HT1A and opioid receptors in the antiallodynic effect of tramadol in the chronic constriction injury model of neuropathic pain in rats. Psychopharmacology (Berl.) 2007;193:97-105.

106. Tao R, Ma Z, Auerbach SB. Influence of AMPA/kainate receptors on extracellular 5hydroxytryptamine in rat midbrain raphe and forebrain. Br J Pharmacol. 1997;121:1707-15.

107.Tao R, Auerbach SB. Increased extracellular serotonin in rat brain after systemic or intraraphe administration of morphine. $\mathrm{J}$ Neurochem. 1994;63:517-24.

108. Alhaider AA, Wilcox GL. Differential roles of 5hydroxytryptamine $1 \mathrm{~A}$ and 5-hydroxytryptamine1B receptor subtypes in modulating spinal nociceptive transmission in mice. $\mathbf{J}$ Pharmacol Exp Ther. 1993;265:378-85.

109.Xu W, Cui X, Han JS. Spinal serotonin IA and IC/2 receptors mediate supraspinal $\mathrm{mu}$ opioid-induced analgesia. Neuroreport. 1994;5:2665-8.

110.Kimura M, Obata H, Saito S. Peripheral nerve injury reduces analgesic effects of systemic morphine via spinal 5-hydroxytryptamine 3 receptors. Anesthesiology. 2014;121(2):362-71.

111. Yesilyurt O, Seyrek M, Tasdemir S, Kahraman S, Deveci MS, Karakus E. The critical role of spinal 5HT7 receptors in opioid and non-opioid type stressinduced analgesia. Eur J Pharmacol. 2015;762:40210 .

112.Kosiorek-Witek A, Makulska-Nowak HE. Morphine analgesia modification in normotensive and hypertensive female rats after repeated fluoxetine administration. Basic Clin Pharmacol Toxicol. 2016;118(1):45-52.

113.Brenchat A, Ejarque M, Zamanillo D, Vela JM, Romero L. Potentiation of morphine analgesia by adjuvant activation of 5-HT7 receptors. J Pharmacol Sci. 2011;116(4):388-91.

114. Shahidi S, Hashemi-Firouzi N. The effects of a 5HT7 receptor agonist and antagonist on morphine 
withdrawal syndrome in mice. Neurosci Lett. 2014;578:27-32.

115.Pettersen VLA, Zapata-Sudo G, Raimundo JM, Trachez MM, Sudo RT. The synergistic interaction between morphine and maprotiline after intrathecal injection in rats. Anesth Analg. 2009;109:1312-7.

116.Ozdemir E, Gursoy S, Bagcivan I, Durmus N, Altun A. Zimelidine attenuates the development of tolerance to morphine-induced antinociception. Indian Journal of Pharmacology. 2012;44(2):215-8.

117. Contreras E, Tamayo L, Quijada L. Decrease of tolerance development to morphine by 5hydroxytryptophan and some related drugs. Eur J Pharmacol. 1973;22:339-43.

118.Liang DY, Li XQ, Clark JD. 5-hydroxytryptamine type 3 receptor modulates opioid- induced hyperalgesia and tolerance in mice. Anesthesiology. 2011;114(5):1180-9.

119.Nayebi AM, Rezazadeh H, Nourafkan M. Buspirone attenuates tolerance to analgesic effect of morphine in mice with skin cancer. Pak J Pharm Sci. 2010;23(2):201-6.

120.Lopez-Gimenez JF, Vilaro MT, Milligan G. Morphine desensitization, internalization, and downregulation of the opioid receptor is facilitated by serotonin 5-hydroxytryptamine receptor coactivation. Mol Pharmacol. 2008;74:1278-91.

Cite this article as: Ozdemir E. The pathophysiological role of serotonin receptor systems in opioid analgesia and tolerance. Int J Basic Clin Pharmacol 2017;6:217-28. 